WELCH, R. B. (1986). Adaptation of space perception. In K. R. Boff, L. Kaufman, \& J. P. Thomas (Eds.), Handbook of perception and human performance: Sensory processes and perception (Vol. 1, pp. 24.1-24.45). New York: Wiley.

Welch, R. B., Choe, C. S., \& Heinrich, D. R. (1974). Evidence for a three-component model of prism adaptation. Journal of Experimental Psychology, 103, 700-705.

WeLCH, R. B., \& Goldstein, G. D. (1972). Prism adaptation and brain damage. Neuropsychologia, 10, 387-394.

WELCH, R., B., \& WARREN, D. H. (1980). Immediate perceptual response to intersensory discrepancy. Psychological Bulletin, 83, 638-667.

Welch, R. B., Widawski, M. H., Harrington, J., \& Warren, D. H.
(1979). An examination of the relationship between visual capture and prism adaptation. Perception \& Psychophysics, 25, 126-132. WiLKINSON, D. A. (1971). Visual-motor loop: A linear system? Journal of Experimental Psychology, 89, 250-257.

\section{NOTE}

1. Preliminary results of this work were presented by Rossetti, Koga, Susami, and Mano (1991).

(Manuscript received December 16, 1991; revision accepted for publication February 11, 1993.)

\title{
34th Annual Meeting of the Psychonomic Society Washington, DC November 5, 6, and 7, 1993
}

The 34th Annual Meeting of the Psychonomic Society will be held in Washington, DC, November 5 , 6, and 7, 1993, at the Omni Shoreham Hotel. The meetings will begin Friday morning and continue until Sunday at noon.

The program and hotel reservation cards will be mailed to members and associates early in September. A copy of the program will be published in the Bulletin of the Psychonomic Society. Additional programs will be available at the registration desk for $\$ 7.00$.

For further information, please contact the Secretary-Treasurer of the Society: Randi C. Martin, Department of Psychology, Rice University, P.O. Box 1892, Houston, TX 77251-1892 (phone: 713-527-8101, ext. 3417; e-mail: rmartina@riceVM1.rice.edu). 